\title{
The Right to Perform Rescue at Sea: Jurisprudence and Drowning
}

\author{
Itamar Mann*
}

(Received 24 February 2020; accepted 04 March 2020)

\begin{abstract}
Framing largescale migrant drownings as violations of international law has so far not been a straightforward task. The failures of doing so, both in scholarship and in activism, have often revealed important limitations of international law, and a form of rightlessness that is hard-wired in it. Through an assessment of arguments about drowning, framed in the vocabularies of the right to life, refugee law, the law of the sea, and international criminal law, difficulties surrounding the notion of jurisdiction persist: The maritime space has often functioned as a kind of "legal black hole." Considering such difficulties, this Article suggests that shifting the focus from migrant rights to the civil and political rights of volunteers coming to the rescue, may help in closing the accountability gap. It thus seeks to articulate and conceptualize a form of maritime civil disobedience among rescue volunteers, which may provide the link for eliminating migrant rightlessness at sea.
\end{abstract}

Keywords: Migration; refugees; jurisprudence; civil and political rights

\section{A. Introduction}

Between January 1, 2014, and November 10, 2019, 33,631 migrants have been reported missing in the Mediterranean Sea and are presumed dead. ${ }^{1}$ Can jurisprudence shed light on the reasons this catastrophe occurred? And what can legal theory teach us about attempts to save those in peril at sea? Beyond the ongoing macabre spectacle at issue is a fundamental question, namely: Under what conditions is it correct to talk of humans as bearers of legal rights? Keeping in mind that the question here is not about moral rights-which may remain firm regardless of enforcement-I have argued elsewhere that such conditions do not always obtain. ${ }^{2}$

\footnotetext{
*Senior lecturer at the University of Haifa, Faculty of Law and Principal Investigator at the Minerva Center for the Rule of Law Under Extreme Conditions. This Article is a deliverable of the MAPS Project, funded by the Jean Monnet Program (2019-2021) 599856-EPP-1-2018-1-IT-EPPJMO-NETWORK, Grant decision 2018-1606/001-001. This Article was first presented at a workshop on "Accountability for Human Rights Violations in Migration Control" held in Oxford on Nov. 10, 2018, that was funded by an ERC Starter Grant RefMig (Grant Agreement 716968), of which Cathryn Costello is the PI. A preliminary version of this Article was first delivered as a short talk at the German Bundestag in September 2018, in the Conference on Civil Search and Rescue Activities-Overcoming the Fortress Europe, hosted by the German Left Party, Die Linke. I thank the organizers of that event, specifically Clara Anne Bünger. I also thank Charles Heller, Frédéric Mégret, Violeta Moreno-Lax, as well as the co-editor of this Special Issue, Cathryn Costello, for invaluable conversations and comments. Nora Markard, editor for the German Law Journal, has provided invaluable insights. Any errors are, of course, mine alone.

${ }^{1}$ See generally Mediterranean Migrant Arrivals Reach 76,558 in 2019; Deaths Reach 1,071, INT'L ORG. FOR MIGRATION (Nov. 10, 2019), https://www.iom.int/news/mediterranean-migrant-arrivals-reach-76558-2019-deaths-reach-1071.

${ }^{2}$ See generally Itamar Mann, Maritime Legal Black Holes: Migration and Rightlessness in International Law, 29 EUR. J. INT'L L. 347 (2018).
}

(C) The Author(s) 2020. Published by Cambridge University Press on behalf of the German Law Journal. This is an Open Access article, distributed under the terms of the Creative Commons Attribution licence (http://creativecommons.org/licenses/by/4.0/), which permits unrestricted re-use, distribution, and reproduction in any medium, provided the original work is properly cited. 
To identify someone's right, we must be able to determine a person or authority with the corresponding duty. ${ }^{3}$

Continuing that argument, this Article argues that rescue activists who voluntarily operate boats to save migrants in distress have an essential role in coupling migrants' rights to states' duties. By putting to use their own rights-bearing bodies, they can generate the conditions in which otherwiserightless persons become bearers of rights. This Article thus aims to complement my previous work in commenting on the now much-discussed topic of maritime migration in order to shed light on broader jurisprudential questions. As deaths in the Mediterranean continue, nearly unabated, civil society attempts to prevent them can teach us an important lesson in legal theory. Hopefully, that lesson can then circle back and bolster efforts to rescue migrants in distress.

As Henry Shue observed long ago, the enforcement of fundamental rights of human beings is best allocated to internationally powerful actors: ${ }^{4}$ States and international organizations. Practically, when it comes to irregular migrants travelling in the Mediterranean, any attempt to accomplish such allocation has been a failure. For years, European governments have chosen not to put an end to preventable deaths, and instead to thwart private actors' attempts to do so. ${ }^{5}$ They have intervened through a host of legal and bureaucratic actions and omissions, often directed against individuals and non-governmental organizations who have initiated private rescue activities. Prosecutions, restrictions upon movement, and confiscation measures directed at activists have had a chilling effect on such rescue activities. ${ }^{6}$ While the number of deaths has decreased over recent years, their rate has grown. ${ }^{7}$ Blocking the civic engagement of activists has been a crucial step in a push to create a "maritime legal black hole" in the Mediterranean: In certain regions of the sea, migrants are travelling while having no de-jure rights to speak of. ${ }^{8}$

Malta and Italy have held rescue vessels such as the Sea Watch 3 and the Iuventa. ${ }^{9}$ The latter's crew has been raising money to lift heavy legal fees. They are exposed to a potential prison sentence for facilitating irregular migration. ${ }^{10}$ In Greece, solidarity volunteers such as Syrian swimmer Sarah Mardini (23) and Sean Binder (24) have been detained for long periods of time. ${ }^{11}$

\footnotetext{
${ }^{3}$ See Wesley Necomb Hohfeld, Fundamental Legal Concepts as Applied in Judicial Reasoning, 23 YALE L.J. 16, 30-31 (1913). See also Henry Shue, Mediating Duties, 98 ETHICs 687, 689 (1988). Though Shue's discussion is not about law, but about morality, his observation is apposite here too: "For every person with a right, and for every duty corresponding to that right, there must be some agents who have been assigned that duty and who have the capacity to fulfill it."

${ }^{4}$ See Shue, supra note 3 , at 697.

${ }^{5}$ See generally, e.g., Sergio Carrera, et. al., Policing the Mobility Society: The Effects of EU Anti-Migrant Smuggling Policies on Humanitarianism, 4 InT'L J. Migration \& Border STUd. 236 (2018); Charles Heller \& Lorenzo Pezzani, Death by Rescue: The Lethal Effects of the EU's Policies of Non-Assistance, Forensic OCEANOGRaPHY (2016), https://deathbyrescue.org/; Charles Heller \& Lorenzo Pezzani, Blaming the Rescuers: Criminalising Solidarity, Re-Enforcing Deterrence, ForENsIC OCEANOGRAPHY (2015), https://blamingtherescuers.org/; Charles Heller \& Lorenzo Pezzani, Mare Clausum: Italy and the EU's Undeclared Operation to Stem Migration Across the Mediterranean (2018), https://content.forensic-architecture.org/ wp-content/uploads/2019/05/2018-05-07-FO-Mare-Clausum-full-EN.pdf; Charles Heller \& Lorenzo Pezzani, Privatised Push-Back of the Nivin, Forensic ARChitecture (DEC. 18, 2019), https://forensic-architecture.org/investigation/nivin.

${ }^{6}$ See Sergio Carrera et al., supra note 5, at 243.

${ }^{7}$ See generally INT'L ORG. FOR MigRATION, supra note 1.

${ }^{8}$ Mann, supra note 2 , at 357.

${ }^{9}$ Germany's Sea-Watch Rescue Boat to Resume Migrant Missions, Deutsche Welle (Dec. 12, 2019), https://www.dw.com/ en/germanys-sea-watch-rescue-boat-to-resume-migrant-missions/a-51742837); The Iuventa Case, [2018] Corte Cost., Cass., (Ita.), https://www.academia.edu/39314474/_ENG_TRANSLATION_IUVENTA_CASE_Italian_Supreme_Court_judgment (translated by Stefano Trevisan and Stefania Carrer) [hereinafter The Iuventa Case]

${ }^{10}$ See Fundamental Rights Considerations: NGO Ships Involved in Search and Rescue in the Mediterranean and Criminal Investigations: Tables and Figures (2015-2018), EUROPEAN UNION AGENCY FOR FUNDAMENTAL RiGHTS, https://fra.europa.eu/ sites/default/files/fra_uploads/fra-2018-ngos-sar-mediterranean_en.pdf (detailing the Iuventa case, as well as other similar cases).

${ }^{11}$ Laura Lynott, 'I'm not a hero but I'm not a criminal'-Trinity Graduate Sean (24) Returns Home After 100 Days in Greek Jail, InDEPENDENT.IE (Dec. 16, 2018), https://www.independent.ie/irish-news/im-not-a-hero-but-im-not-a-criminal-trinitygraduate-sean-24-returns-home-after-100-days-in-greek-jail-37631116.html; Syrian Refugee Activist Released from Greek Prison, DeuTsCHe Welle (Jan. 2, 2019), https://www.dw.com/en/syrian-refugee-activist-released-from-greek-prison/av46923406.
} 
As I write these words, human rights defender Salam Aldeen, who has been acquitted of trafficking charges, is once again detained on Lesvos. ${ }^{12}$ In private conversations, activists offer varying accounts of the new environment that has emerged due to policies designed to silence them. Some members of rescue crews have described a reality in which even people who "merely provide towels or blankets" express fear and "keep a lawyer's number handy." ${ }^{13}$ Others have shared their dilemmas - at times acknowledging that their activity may indirectly assist people smugglers and expose them to legal risks. When it comes to irregular migrants who cannot obtain authorization to travel by cheap and safe maritime routes, "[t]he Mediterranean Sea is closing down." 14

In response to such measures, advocates have asserted migrants' rights-primarily the right to life, rights under refugee law, and rights under the law of the sea. Several scholars and activiststhe present author included-have thrown international criminal law into the mix. ${ }^{15}$ And yet, any attempt to fill the lacuna may not succeed, unless, alongside the rights of migrants, the rights of rescue activists too are put to use. ${ }^{16}$ At a high level of abstraction, at the basis of human rights is a dyadic encounter between powerful individuals representing states and otherwise-rightless individuals. ${ }^{17}$ "De jure rightlessness" is the result of such an encounter being systematically prevented. ${ }^{18}$ We must therefore view this encounter not only from the migrants' perspective; not less important is the perspective of those representing the power of states. As I will demonstrate below, due to the rules of jurisdiction-as well as rules of the law of the sea-maritime space offers an important peculiarity: The role of coupling rights to duties is ascribed to state agents as well as civil society actors. ${ }^{19}$

Throughout the Article I invoke the notions of rights and duties. As explained in Part B, I take my cue from classical work by W. N. Hohfeld ${ }^{20}$ - as well as from Pierre Schlag's 2015 appeal to "do things with Hohfeld" ${ }^{21}$ Part C seeks to concretize and illustrate the discussion. It explains the possibilities and limitations of four bodies of law in coupling the rights of migrants at sea with

\footnotetext{
${ }^{12}$ Amnesty International, Public Statement, Amnesty Calls on Greece to Urgently Disclose the Evidence for the Proposed Deportation of Human Rights Defender Helping Refugees in Lesvos (Dec. 19, 2019), https://www.amnesty.org/download/ Documents/EUR2516122019ENGLISH.pdf.

${ }^{13}$ Private conversations, in author's notes.

${ }^{14}$ Charles Heller \& Lorenzo Pezzani, Contentious Crossings: Struggles and Alliances for Freedom of Movement across the Mediterranean Sea, 118 S. ATL. Q. 644, 644 (2019).

${ }^{15}$ See generally, e.g., Claire Henderson, Australia's Treatment of Asylum Seekers: From Human Rights Violations to Crimes Against Humanity, 12 J. InT'L CRIM. Just. 1161 (2014); Ioannis Kalpouzos \& Itamar Mann, Banal Crimes Against Humanity: The Case of Asylum Seekers in Greece, 16 MelB. J. InT'L L. 1 (2015); Itamar Mann, Violeta Moreno-Lax \& Omer Shatz, Time to Investigate European Agents for Crimes against Migrants in Libya, EJIL: TALK! (Mar. 29, 2018), https://www.ejiltalk.org/timeto-investigate-european-agents-for-crimes-against-migrants-in-libya/.

${ }^{16}$ Such arguments have of course already been voiced in the context of the legal defense of rescue activists subject to criminalization attempts. See, e.g., The Iuventa Case.

${ }^{17}$ Itamar Mann, Humanity at Sea: Maritime Migration and the Foundations of International Law 232 (2016); Moritz Baumgärtel, Demanding Rights: Europe's Supranational Courts and the Dilemma of Migrant VULNERABILITY 101-20 (2019).

${ }^{18}$ BAUMGÄRTEL, supra note 17, at 101-20. The condition of de facto rightlessness is characterized by the fact that it can betheoretically - countered by invoking international law and calling for its enforcement. In the case of de jure rightlessness, however, the attempt to identify the subjects responsible for the abuse-states, corporations and individuals—and call for their legal accountability is ab initio rendered futile. See also Adel-Naim Reyhani, Anomaly on Anomaly: Refugee Law and the Disintegration of a Transit State (2020) (working paper) (on file with author).

${ }^{19}$ United Nations Convention on the Law of the Sea (UNCLOS), art. 98, para. 1, Dec. 10, 1982, 1833 U.N.T.S. 397, provides that "[e]very State shall require the master of a ship flying its flag" to render assistance to vessels in distress, when the conditions allow for it. It thus puts private individuals, rather than states, in the position of providing a certain (limited) measure of basic protections to humans as such. To be sure, many human rights are enabled only by other individuals: The right to marry means individual must find another willing individual; the right to association needs a group. But in such cases, the right is realized in common, but the corresponding duty still belongs to a state.

${ }^{20}$ Hohfeld, supra note 3.

${ }^{21}$ Pierre Schlag, How to do Things with Hohfeld, 78 L. \& ConTemp. Probs. 185 (2015) (arguing that Hohfeld's work is unique in the terrain of analytical jurisprudence, in having a "critical bite" that has not yet been fully explored).
} 
refugee duties: The right to life (Part C.I.); refugee law (Part C.II.); the law of the sea (Part C.III.); and international criminal law (Part C.IV.). Taken together, the shortcomings of these draw the contours of the "maritime legal black hole" I have previously identified. Part D turns to the civil and political rights of rescuers, such as the freedom of expression and the right to assembly and association (Part D.I.). It then develops a theoretical understanding of "maritime civil disobedience," following Hannah Arendt's conceptualization of civil disobedience (Part D.II.). ${ }^{22}$ By their very nature, the scope of such political rights cannot be determined in advance; it is to a large extent the result of the intensity in which they are performed and put to the test. Part E briefly concludes.

\section{B. Human Rights and Duties at Sea}

Analytically, "rights" can be said to exist only when the right of person $a$ corresponds to the duty of person or authority $x$. Such "jural relations" between the two "correlates," as Hohfeld called them, are the very meaning of having rights. Duties vary across the legal terrain. They may be, for example, duties of compensation, consideration, hearing, or investigation-or indeed duties to perform rescue. ${ }^{23}$ While the title of this Article may suggest my discussion is about the latter, that is not the case, at least not exclusively; rather, the Article seeks to identify how the fulcrum upon which any such duty comes to exist appears in the first place. ${ }^{24}$

Hohfeld's work is admittedly more often discussed by theorists of private law, but his ambition covered private as well as public law to offer a comprehensive picture of legality. ${ }^{25}$ Schlag recently explained Hohfeld's taxonomy concisely:

Hohfeld described four kinds of entitlements (rights, privileges, powers, and immunities) and four kinds of disablements (duty, no right, liability, and disability). For each entitlement there is always a unique and distinct correlative disablement and vice versa. Thus, for every right in $\mathrm{A}$, there must be a correlative duty in B. For every privilege in A, there must be a correlative $\ldots$ [no-right] (and so on and so forth). ${ }^{26}$

Duties may belong to public or private law. When the rights of person $a$ are invoked, but no corresponding duty can be identified de jure and attached to any specific actor, the invocation of rights is erroneous. Rather than engaging the vast philosophical commentary following Hohfeld, this Article will more modestly seek to build on this basic insight about rights and privileges. It seeks to show what scholars of global migration law can "do" with it. ${ }^{27}$ As Schlag has argued, Hohfeld provides a particularly useful frame of analysis for scholarship aiming to highlight not only the possibilities of law, but also its limitations. The Hohfeldian framework for legal analysis thus emerges as a "scene of conflict, mediated and administered through law's allocation of wealth and power." 28

\footnotetext{
${ }^{22}$ Hannah Arendt, Civil Disobedience, in Crisis of THe Republic 51 (1972).

${ }^{23}$ In their contribution to this Special Issue, Tan and Gammeltoft-Hansen emphasize the respective relevance to human rights of remedies from different legal disciplines. Nikolas Feith Tan \& Thomas Gammeltoft-Hansen, A Topographical Approach to Accountability for Human Rights Violations in Migration Control, in this issue.

${ }^{24} C f$. Arendt's notion of "the right to have rights." See Hannah Arendt, Origins of Totalitarianism 296 (1976) (providing an illuminating application in the context of international law); Alison Kesby, The Right to Have Rights: Citizenship, Humanity, AND INTERNATIONAL LAW (2012) (same).

${ }^{25}$ Nicholas Bamforth, Hohfeldian Rights and Public Law, in Rights, Wrongs AND Responsibilities 1 (Matthew H. Kramer ed., 2001).

${ }^{26}$ Schlag, supra note 21 , at 188 .

${ }^{27}$ Schlag, supra note 21. See generally Jaya Ramji-Nogales \& Peter J. Spiro, Introduction to Symposium on Framing Global Migration Law, 111 AJIL UNBOUND 1 (2017) (providing background on the emergence of global migration law as a discipline in the last few years).

${ }^{28}$ Schlag, supra note 21 , at 233.
} 
Following the terminology introduced by Hohfeld, one observes that $x$ may have the duty to "render assistance" to person $a$-by rescue at sea-in which case person $a$ will have a right to be rescued. ${ }^{29}$ Alternatively, depending on their location, $x$ may have a "privilege" to decide whether to "render assistance" to person $a$ or not. In the latter case, person $a$ has a correlative relation of "no-right" towards $x .^{30}$ If no other authority has a rights-duties relationship with $a$, the latter's right is extinguished. Assuming that person $a$ had no enforceable rights where she came from, and was therefore de facto rightless, $a$ is now found to be de jure rightless. In the former situation there was a state that could not fulfill its duties and fleeing from it was a necessity; in the latter situation no such state exists. Because of the law's allocation of duties according to jurisdictional limitations, the problem of mass drowning in the Mediterranean presents itself as such a problem of de jure rightlessness. But come closer to the person at risk, and your privilege to rescue them will transform, due to rules of the law of the sea, into a duty to do so; the drowning person's de jure rightlessness becomes a relationship of rights and duties. The drowning person has a claim upon you.

The following parts of this Article seek to answer the question, how is that transformation achieved? And, more precisely, what specific legal rights are involved?

\section{Migrant Rights \\ I. The Right to Life}

Perhaps the most intuitive place to begin an inquiry on the rights of the numerous migrants that have been drowning in the Mediterranean, is the right to life. ${ }^{31}$ Pope Francis's statement from 2013, according to which the Mediterranean has become a "vast cemetery," has perhaps become a bitter cliché. ${ }^{32}$ But widespread deaths in the central Mediterranean certainly still present a question with momentous practical and legal implications. What can be more natural than turning to the right to life? This right is protected by the major human rights treaties, including Article 6 of the International Covenant on Civil and Political Rights; Article 2 of the European Convention on Human Rights; and Article 2 of the Charter of Fundamental Rights of the European Union. And the right applies regardless of nationality. The preamble of the Universal Declaration of Human Rights refers to the rights of "all members of the human family." 33

\footnotetext{
${ }^{29}$ Hohfeld, supra note 3. See UNCLOS, supra note 19, at art. 98 (codifying customary international law). Cf. generally Seline Trevisanut, Is There a Right to be Rescued at Sea? A Constructive View, 4 Questions INT'L L. 3 (2014). Note that under the treaty, the state has a duty to require its flag ship to render assistance, for example, the duty belongs to a state signatory and the corresponding "right" is granted to other state signatories. Under this construction the state then imposes duties on its flag ships, with the correspondent rights attaching to those who are in distress at sea. This duty which one private person can owe towards another person originates in custom, and has roots in natural law, in the Christian (Grotian) tradition, and in the Islamic tradition. See MANN, supra note 17, at 212; Hassan S. KhalilieH, Islamic Law of the Sea: Freedom of Navigation and Passage Rights in Islamic Thought 195 (2019). See generally Martin Ratcovich, International Law and the Rescue of Refugees at SEA (2019), https://www.diva-portal.org/ smash/get/diva2:1323140/FULLTEXT02.pdf.

${ }^{30}$ Person $a$ may of course still have an interest in being rescued, as well as a "moral right" to that—if indeed it makes sense to talk about rights in a purely moral register.

${ }^{31}$ See, e.g., Thomas Spijkerboer, Wasted Lives. Borders and the Right to Life of People Crossing Them, 86 NORDIC J. INT'L L. 1 (2017).

${ }^{32}$ Pope Francis Complains of 'Haggard' Europe in Strasbourg, BBC News (Nov. 25, 2014), https://www.bbc.com/news/ world-europe-30180667. See also Karen Knop \& Susan Marks, The War Against Cliché: Dispatches from the International Legal Front, in Sovereignty, Statehood and State Responsibility (Christine Chinkin \& Freya Baetens eds., 2015). In their essay about clichés in international law, Susan Marks and Karen Knop list the "legal black hole," a concept I make some use of here, as one such example of "resonant expressions" that "become, in some sense, victims of their own success."

${ }^{33}$ See G.A. Res. 217 (III) A, Universal Declaration of Human Rights (Dec. 10, 1948).
} 
This universality is a feature of human rights law generally, which may suggest that people have rights always and everywhere. As one commentator has written, "no human being is without protection under international law ... in every circumstance, every human being has some forms of protection under human rights law." 34 This view reflects a widely-held understanding of human rights as a universal moral baseline. ${ }^{35}$ According to this view, it may appear that persons have all human rights everywhere they may be found, regardless of the rights' enforcement. When migrants die by preventable drownings in the Mediterranean, it may seem like their right to life is ipso facto violated. These are unnecessary deaths, with no legal justification whatsoever. ${ }^{36}$ What can be a clearer violation of the right to life?

For a human rights violation to occur, however, one must be able to clearly identify a state that has carried out a violation. Put differently, person $a$ 's right must be coupled with authority $x$ 's duty. When migrants drown en masse, it has often proven impossible, due to lack of jurisdiction, to make that connection between right and duty. It is thus not merely by dint of politics or other extra-legal factors that the right to life has so far largely been ineffective in establishing accountability for migrant deaths by drowning. ${ }^{37}$ The continued migrant deaths in the Mediterranean, with the relative toleration of legal institutions of the matter, is due to the structure of law-human rights law included. ${ }^{38}$ As Ralph Wilde writes in an illuminating work-in-progress:

[I]nternational law only addresses the rights of a narrow sub-set of migrants, and in partial fashion. Only a limited proportion of people who feel compelled to move are given the right to stay where they move to .... For the privileged group, these rights apply only if they manage to reach the territory, or fall under the extraterritorial control, of third states. ${ }^{39}$

Surely, some cases of migrant deaths have indeed been violations of the right to life. The last thing I would like to do is to interpretively reduce the set of cases in which the right to life does provide a legal basis for migrant claims. The European Court of Human Rights' (ECtHR) Hirsi case has found that human rights jurisdiction can extend to the high seas. ${ }^{40}$ And, as Violeta MorenoLax and Mariagiulia Giuffré have argued, the application of human rights jurisdiction under Hirsi requires either de-jure or de-facto jurisdiction; for example, de-facto control over a migrant alone suffices to trigger human rights obligations and the jurisdiction of the ECtHR. ${ }^{41}$

Although, in many cases of migrant drownings no such control exists. It is hence not possible under extant law to establish accountability in terms of correspondence between the right to life and a state duty. ${ }^{42}$ Such are cases in which a migrant boat in distress does not come under the

\footnotetext{
${ }^{34}$ Jordan J. Paust, Post 9/11 Overreaction and Fallacies Regarding War and Defense, Guantanamo, the Status of Persons, Treatment, Judicial Review of Detention, and Due Process in Military Commissions, 79 Notre Dame L. Rev. 1350, 1350-51 (2004).

${ }^{35}$ See generally Seyla Benhabib, Another Universalism: On the Unity and Diversity of Human Rights, 81 PROC. \& ADDRESSES APA 9 (2007).

${ }^{36}$ No one seriously argues that they are necessary on national security grounds; no one frames them as punishment, even if capital punishment could be consonant with the right to life.

${ }^{37}$ Mann, supra note 2, at 369.

${ }^{38} \mathrm{Cf}$. Tugba Basaran, The Saved and the Drowned: Governing Indifference in the Name of Security, 46 SECURITY DIALOGUE 205, 205-20 (2015); Ralph Wilde, The Unintended Consequences of Expanding Migrant Rights Protections, 111 AJIL: UNBOUND 487 (2017).

${ }^{39}$ Ralph Wilde, The Migration and Refugee 'Crisis' in International Law (2019) (work in progress) (emphasis added) (on file with author).

${ }^{40}$ Hirsi Jamaa \& Others v. Italy, App. No. 27765/09 (Feb. 23, 2012). http://hudoc.echr.coe.int/eng?i=001-61572.

${ }^{41}$ See Violeta Moreno-Lax \& Mariagiulia Giuffré, The Rise of Consensual Containment: From 'Contactless Control' to 'Contactless Responsibility' for Forced Migration Flows, in Research Handbook on International Refugee Law (Satvinder Juss ed., 2019).

${ }^{42}$ As the co-editor of this Special Issue, Cathryn Costello has commented that a rights-duties relationship is not the only notion of (legal) accountability. I take this relationship to be central to accountability in general, even if not exhaustive.
} 
de-facto "control" of an actor bound by human rights law-such as Italy. To be sure, transit states such as Libya are also bound by human rights law, even if with a thinner basis in treaty. ${ }^{43}$ But before they embark and travel on the maritime common, beyond any state's territorial jurisdiction, the Libyan example reveals that enforcement may be entirely lacking, ${ }^{44}$ to the point of national disintegration and even questionable sovereignty. ${ }^{45}$ This may be true even when a functioning state such as Italy could perform rescue on its own, if it would only choose to do so and spend the necessary resources. The jurisdictional limitations of human rights entail that death can be preventable by a certain state and still not amount to a human rights violation by that state when they do occur. ${ }^{46}$

To be sure, there are important doctrinal discussions seeking to expand jurisdiction, some of them specifically concerning the right to life. ${ }^{47}$ Think of the next step Moreno-Lax and Giuffré take in their analysis, interpretively arguing for the recognition of "contactless control" as the basis for human rights duties. In my own advocacy work, I have also tried to contribute to these discussions before relevant tribunals. ${ }^{48}$ Be that as it may, there are areas in the Mediterranean where, one must admit, migrants have been drowning beyond the jurisdiction of states-as a matter of lex lata. ${ }^{49}$ These migrants are outside of a state's territorial waters, and beyond the de-facto control of its flag ships, governmental or private. They may be outside of a state's Search and Rescue (SAR) area-where the state still has positive obligations to facilitate rescue operations, some would say undergirded by the right to life. Such cases are, prima facie, not violations of the right to life-once again — even if deaths could have conceivably been prevented.

One relatively familiar example illustrates the perplexity arising at the limit-points of human rights jurisdiction. Think of the "left-to-die" boat of $2011 .^{50}$ After having left Tripoli and sent distress signals that were received by the Maritime Rescue Coordination Center in Rome, the boat was allegedly ignored by multiple vessels. Sixty-three migrants consequently found their deaths by

\footnotetext{
${ }^{43}$ For Libya's ratification status for the major human rights treaties, see Ratification Status for Libya, U.N. HUMAN RIGHTS: OfFICE OF THE HIGH COMMISsIONER, https://tbinternet.ohchr.org/_layouts/15/TreatyBodyExternal/Treaty.aspx?CountryID $=99 \&$ Lang $=\mathrm{EN}$. Crucially, Libya is not a party to the Refugee Convention. It is of course also not a party to the European Convention on Human Rights, but is - unlike non-African states - a party to African Charter on Human and Peoples' Rights.

${ }^{44}$ This is what I have called de facto rightlessness.

${ }^{45}$ The disintegration of transit states raises a host of relevant issues concerning the recognition of such states. Since 2011, Libya has become the site of constant clashes between armed groups, raising the question whether it is still a state that can have obligations under international law. See Reyhani, supra note 18. The question opens a wider debate from a couple of decades back, on the appropriate international legal understanding of failed states. See, e.g., Rosa Ehrenreich Brooks, Failed States, or the State of Failure, 72 U. CHI. L. Rev. 1159 (2005). But see Ralph Wilde, The Skewed Responsibility Narrative of the "Failed States" Concept, 9 ILSA J. INT'L \& COMP. L. 425 (2002) (offering an opposing view).

${ }^{46}$ See Spijkerboer, supra note 31, at 20, 24 (observing that in irregular migration, jurisdiction is applied in a traditional manner and hence poses serious limitations on the universal application of the right to life: "There is a remarkable differentiation in flexibility and inventiveness, with aviation law as a playground for legal creativity, and on the other end of the spectrum the law protecting the life of irregularised travelers with a static notion of jurisdiction"). See generally also Itamar Mann, Dialectic of Transnationalism: Unauthorized Migration and Human Rights 1993-2013, 54 HARV. INT'L L. J. 315 (2013).

${ }^{47}$ See Human Rights Committee (HRC), International Covenant on Civil and Political Rights art. 6, general comment 36, 2018, G.A. Res. 2200A; Violeta Moreno-LaX, ACCessing Asylum in Europe: Extraterritorial Border Controls and REFUgEe Rights UNDER EU LAW (2017) (note especially chapter 10 on the "Unavoidability of Admission to Territory").

${ }^{48}$ See generally Noemi Magugliani, Itamar Mann \& Violeta Moreno-Lax, Communication to the United Nations Human Rights Committee in the Case of SDG v Italy, ACADEMIA (2019), https://www.academia.edu/41462159/Communication to_the_United_Nations_Human_Rights_Committee_In_the_case_of_SDG_v_Italy; Legal Action Against Italy Over Its Coordination of Libyan Coast Guard Pull-Backs Resulting in Migrant Deaths and Abuse, GLOBAL LEGAL Action NETwORK (May 8, 2018), https://www.glanlaw.org/single-post/2018/05/08/Legal-action-against-Italy-over-its-coordinationof-Libyan-Coast-Guard-pull-backs-resulting-in-migrant-deaths-and-abuse.

${ }^{49}$ Wilde, supra note 39; Mann, supra note 2.

${ }^{50}$ The "Left-to-Die Boat": Actions and Reactions, Council of Europe Parliamentary Assembly (June 24, 2014), https:// assembly.coe.int/nw/xml/XRef/Xref-XML2HTML-en.asp?fileid=21024\&lang=en. See generally also CHARLES HELLER \& Lorenzo Pezzani, The Left to Die BoAt (2014); Mann, supra note 17, at ch. 4.
} 
drowning. Accountability for the lives of such migrants may be anchored in the duty of rescue under the law of the sea, as discussed below. ${ }^{51}$ If we follow Seline Trevisanut, it is also based on Italy's obligation under the right to life. ${ }^{52}$ If Italy had failed to exercise due diligence in securing rescue for the boat, it could perhaps have been held accountable at a human rights tribunal or committee. On the one hand, the argument would be that Italy has not fulfilled its positive obligations in facilitating maritime rescue activities and has therefore violated the right to life. On the other hand, it seems that the left-to-die boat has not come under Italy's "control," de facto or de jure. It is therefore, at the very least, questionable whether a human rights body-such as the ECtHR — could assert jurisdiction over what had transpired. ${ }^{53}$ With no jurisdiction, there would of course be no finding of a violation of the right to life.

It is perhaps tempting to say that because asylum seekers have a right to life, they also have $a$ right to be rescued. There is some appeal to this argument. But such a right to be rescued does not stand on its own. Rather, it relies on the rights that a potential rescuer had, independent of any refugee or asylum seeker. If an activist chooses to act on behalf of migrants whose life are risked at sea, the rescuer's choice is not protected by the rescuees' right to life. It is protected by the rescuer's rights of political participation, such as her freedom of expression and her right to assembly-as discussed in Part D below. As we will see, by exercising her own human right, the solidarity activist may put herself in a position where she also has a duty, under the law of the sea, to perform the rescue operation. State duties starting from granting the right to disembark will be triggered from the solidarity activist onward to a state; these will fall in place like the next pieces of a domino trail. Ultimately, what we are looking for here is a way to close a circle which states have systematically tried to unfasten: Coupling rights to specific, determinate duties.

\section{Refugee Law}

Another important area to consider in trying to fill the "maritime legal black hole" is refugee law. There is a certain symmetry between the problem of mass death and the right to life. But the latter has arguably not been the most useful for advocates contesting violent border policies in the Mediterranean. Rights enshrined in refugee law writ large have, perhaps, been appealed to more often. If indeed drowning has been a lesser legal issue than returns to countries of persecution, such as Libya, this attests to the relative dominance of refuge law in this area. But does a focus on refugee law fare better in responding to mass drowning?

Refugee law grants considerable rights to refugees who suffer a well-founded fear of persecution. ${ }^{54}$ The duty of non-refoulement also provides robust protections against return for those at risk of torture, inhuman or degrading treatment, or other serious human rights violations ${ }^{55}$ Eminent commentators, as well as the United Nations High Commissioner for Refugees, have argued that the principle of non-refoulement also enjoys the status of customary international law. ${ }^{56}$ Persecution and treatment contrary to peremptory norms of international law

\footnotetext{
${ }^{51}$ See generally Efthymios Papastavridis, The European Convention of Human Rights and Migration at Sea: Reading the 'Jurisdictional Threshold' of the Convention under the Law the Sea Paradigm, in this issue.

${ }^{52}$ Trevisanut, supra note 29, at 14 . But see Efthymios D. Papastavridis, Is There a Right to be Rescued at Sea? A Skeptical View, 4 Questions INT'L L. 17, 24-29 (“[I]t is the view of the present author that such a 'operational obligation' derives only from the normative framework of human rights law and it cannot be transposed to the law of the sea context ... only in the case that the prerequisite of 'jurisdiction' is met, we can speak of a 'right to be rescued', as inherent in the right to life.").

${ }^{53}$ See Papastavridis, supra note 52.

${ }^{54}$ See generally Guy S. Goodwin Gill \& Jane McAdam, The Refugee in International Law (3d. ed. 2007); Vincent Chetail, International Migration LaW 166-99 (2019).

${ }^{55}$ Convention Relating to the Status of Refugees art. 33, July 28, 1951, 189 U.N.T.S. 137; CHETAIL, supra note 54, at 194-99.

${ }^{56}$ See, e.g., Cathryn Costello \& Michelle Foster, Non-refoulement as Custom and Jus Cogens? Putting the Prohibition to the Test, NeTH. Y.B. INT'L L. 273 (2015). This customary status, however, remains controversial.
} 
is rife in some countries of embarkation-certainly in Libya. ${ }^{57}$ But the key question here is whether refugees have rights to protection under refugee law even before they access state jurisdiction, such that may be a basis for protection against drowning.

The United Nations High Commissioner on Refugees (UNCHR) has long explained that "determination of refugee status can only be declaratory in nature ... any person is a refugee within the framework of a given instrument if he meets the criteria of the refugee definition in that instrument, whether he is formally recognized as a refugee or not." 58

In other words, even before a state has a duty to process an asylum request and determine its merits, bona fide refugees are already "refugees" for the purpose of Article 1 of the 1951 Refugee Convention. Commentators have argued that practices of non-entrée, seeking to disallow access to asylum extraterritorially, are often illegal. ${ }^{59}$ Some of the public discourse over the last few years has mirrored this legal discussion. ${ }^{60}$

The underlying legal principle of non-refoulement should of course be upheld, but one would be hard-pressed to find in them a legal protection against widespread migrant drownings. The problem here is essentially the same as the problem in the context of the right to life: It is one of jurisdiction. Prior to when they have accessed the jurisdiction of a state bound by refugee law, their claimed rights to international protection do not have a corresponding duty attached to a specific legal person. There is a split between European and United States courts regarding the question of when exactly a refugee comes under state jurisdiction. ${ }^{61}$ The U.S. Supreme Court has found that the prohibition of refoulement is established only when a refugee enters U.S. territory. ${ }^{62}$ The European Court of Human Rights, for its own part, responded that extraterritorial control over an asylum seeker already triggers the protection from refoulement. ${ }^{63}$ On the academic side, commentators have generally supported the latter point of view. ${ }^{64}$ Be that as it may, the legal systems do not recognize state duties towards refugees before they enter the relevant state's jurisdiction. Furthermore, observe that drowning is not refoulement. Otherwise, the 1951 Convention would contain a right to safe passage, to be secured by the country of destination. Indeed, it is not even entirely clear whether non-admission at high sea-for example, by impeding their further passage-is refoulement, if the effect is not to push the refugees back, but instead to leave them at high sea. ${ }^{65}$ Refugees beyond jurisdiction are a rather good example of a

\footnotetext{
${ }^{57}$ See generally United Nations Support Mission in Libya \& Office of the U.N. High Comm'r for Human Rights, "Detained and Dehumanised": Report on Human Rights Abuses Against Migrants in Libya (Dec. 13, 2016), https://www.ohchr.org/ Documents/Countries/LY/DetainedAndDehumanised_en.pdf.

${ }^{58}$ U.N. High Comm'r for Refugees, Note on Determination of Refugee Status under International Instruments EC/SCP/5 (Aug. 24, 1977), https://www.unhcr.org/excom/scip/3ae68cc04/note-determination-refugee-status-under-internationalinstruments.html.

${ }^{59}$ The fundamental argument under refugee law, which has historically been articulated in an elegant way by Justice Harry Blackmun of the United States Supreme Court, is that policies of non-entrée render the norm of nonrefoulement irrelevant. See Sale v. Haitian Centers Council, Inc., 509 U.S. 155, 158-59 (1993). Cf. JAMES C. Hathaway, The Rights of Refugees Under International LaW 336-67 (2005); Moreno-Lax, supra note 47; Nora Markard, The Right to Leave by Sea: Legal Limits on EU Migration Control by Third Countries, 27 EUR. J. INT'L L. 591 (2016).

${ }^{60}$ Al-Jazeera America, for example, has declared at one point that the word "migrants" will no longer be used. Asylum seekers can be "refugees" even before any formal determination to that effect. See Barry Malone, Why Al Jazeera Will Not Say Mediterranean 'Migrants', AL-JAZEERA (Aug. 20, 2015), https://www.aljazeera.com/blogs/editors-blog/2015/08/aljazeera-mediterranean-migrants-150820082226309.html.

${ }^{61}$ Mann, supra note 46 , at 355-63.

${ }^{62}$ See Sale, 509 U.S. at $158-59$.

${ }^{63}$ Hirsi, App. No. $27765 / 09$ at 80 .

${ }^{64}$ See, e.g., Roland Bank, Introduction to Article 11, in The 1951 Convention Relating to the Status OF ReFugEES AND its 1967 Protocol 848 (Andreas Zimmermann ed., 2011); Goodwin-Gill \& MCAdAM, supra note 54, at 207.

${ }^{65}$ Cf. Ruddock v Vadarlis, [2001] F.C.A. 1329, paras. 193, 213 (Sep. 18, 2001) (Austl.).
} 
situation in which international law asserts that person $a$ has a right, but no authority $x$ has the corresponding duty. ${ }^{66}$

When an Italian fisherman is prosecuted for a trafficking or a smuggling crime, after having saved a drowning migrant, this may influence future conduct. It may, for example, increase the probability that the next migrant drowns, as the next fisherman may be deterred from helping. But is the duty of non-refoulement immediately breached? That would be a stretch. Certainly, such prosecutions help generate the environment in which the duty of non-refoulement is gradually eroded. But it is still not clear that such prosecutions are a breach of the non-refoulement obligation per se. Refugee law is about protections for refugees, and to a certain extent about the governance of borders. It is not about preventing drownings and not about rescuing those who risk their lives at sea. One must find the anchor for the rights of drowning migrants elsewhere or conclude that such an anchor simply does not exist.

\section{The Law of the Sea}

Why talk about a right to perform rescue at all, when the Law of the Sea enshrines a duty of rescue? Under Article 98 of the United Nations Convention on the Law of the Sea, ${ }^{67}$ which reflects customary international law, "[e]very state shall require the master of a ship flying its flag" to "render assistance" when informed of a boat in distress. Under the Safety of Life at Sea Convention, too, the duty to facilitate and coordinate acts of rescue is imposed upon states. ${ }^{68}$ If a duty of rescue at sea obtains, it seems trivial to talk about a right to perform rescue. What is the point in insisting that one is legally permitted to do what they are already legally obliged to?

The maritime duty of rescue is crucial for rescue activities. As will become clear below, the maritime duty to render assistance constitutes a legal link between activists and migrants, which activists can use in order to rectify migrants' rightlessness. But before that can be demonstrated, readers should also acknowledge the limits to its application. ${ }^{69}$ Under the 1979 International Convention on Maritime Search and Rescue, governmental agencies have a duty to coordinate rescue in their respective SAR Zones. ${ }^{70}$ They also have the duty to make sure that vessels flying their flags initiate rescue activities when they are informed of a vessel in distress and can provide help. ${ }^{71}$ The latter requirement, which applies on the high seas, obtains when it can be carried out "without serious danger to the ship, the crew or the passengers." ${ }^{\text {" It }}$ is triggered when flag ships have some physical proximity to vessels in need of rescue. ${ }^{73}$

But there are surely vessels sailing on the high seas, in need of rescue, where no specific actor has the legal duty to perform rescue. Protections for migrants who have been forced to choose between de facto rightlessness, and perilous journeys at sea, might not exist simply by application of the law of the sea. ${ }^{74}$ This may occur beyond states' SAR zones, or even in such zones-if no other vessel is around. ${ }^{75}$ At present, it may also occur in Libya's recently-declared

\footnotetext{
${ }^{66}$ The fact that the international legal right to seek asylum apparently has no corresponding duty to obtain asylum was famously derided by one of the fathers of international human rights law, Hersch Lauterpacht. For discussion, see CHETAIL, supra note 54, at 191; MANN, supra note 17, at 29-41.

${ }^{67}$ UNCLOS, supra note 19.

${ }^{68}$ International Convention for the Safety of Life at Sea (SOLAS), annex ch. 5, reg. 15, May 25, 1980, 1184 U.N.T.S.

${ }^{69}$ See Papastavridis, supra note 51.

${ }^{70}$ International Convention on Maritime Search and Rescue (SAR), annex 3.1, Apr. 27, 1979, 1403 U.N.T.S.

${ }^{71}$ UNCLOS, supra note 19 , at art. 98.

${ }^{72}$ UNCLOS, supra note 19 , at art. 98.

${ }^{73}$ See SAR, supra note 70, at annex 5.3.3.5. Cf. Papastavridis, supra note 51 (providing an emphasis on "visual contact").

${ }^{74}$ See Mann, supra note 2, at 371 (addressing the curious combination of duress and choice in this context, complicating questions of migrant agency).

${ }^{75}$ Note that if the Maritime Rescue Coordination Center receives a distress signal, it has to act upon it. SAR, supra note 70 , annex 5.3.3.
} 
SAR zone, ${ }^{76}$ where Libya is not willing or able to render authentic rescue- a monumental understatement. ${ }^{77}$ These are the areas I have called "maritime legal black holes." In such areas, humans may find themselves de-jure rightless. ${ }^{78}$

Italy has taken on rescue operations beyond its SAR zone during operation Mare Nostrum (2013-2014). Surely, Italy had a privilege, under international law, to initiate a rescue operation at sea. Once the operation was in place, and Italy's vessels were in a position to do so even beyond Italy's maritime space, Italian vessels also had a duty to assist. As Heller and Pezzani have documented, when that operation ended, the EU decided to deploy a much more limited operation without a rescue mandate (Operation Triton, now replaced by Operation Themis). Private volunteer vessels aimed to step in and fill the gap. ${ }^{79}$ Yet, states aiming to chill rescue operations, including not only Italy but also Malta and Greece-with an umbrella of EU backing-placed limitations on the freedom of movement at sea upon rescue volunteers. The latter were part of the system by which rescue at sea was ultimately, in many cases, criminalized.

Ever since, we have been living through a constant push-and-pull dynamic between states imposing laws to limit rescue and solidarity activists engaging in a form of maritime civil disobedience. Granted, neither group is homogenous in the kinds of relationships it establishes with the law. ${ }^{80}$ What is clear nonetheless, is that the law of the sea in and of itself cannot always decide between the opposing forces. And when maritime law is superimposed with a layer of domestic criminal limitations designed to quell rescue activities, the maritime duty of rescue cannot prevent widespread deaths by-preventable-drowning.

In this context, another fundamental principle of the law of the sea emerged as crucial for asserting a right to perform rescue. This is the freedom of navigation, also referred to as the freedom of movement on the high seas. ${ }^{81}$ Beyond narrow exceptions, international law does not permit states to limit the movement of vessels, private solidarity and rescue vessels included. This principle, however, does not apply in Libyan territorial waters, where there are serious security risks for migrants. Libya has arguably, since 2011, been more of a battleground for rival armed groups than a state with effective control over its territory. ${ }^{82}$ For most international lawyers, however, Libya remains recognized as a sovereign state, protected by the principle of nonintervention. ${ }^{83}$ If this is indeed the case, Libya retains authority to exclude seafarers from its territorial waters-except for "innocent passage" under the law of the sea. ${ }^{84}$ As will become clear below, the question whether such passage is "innocent" or not cannot be determined solely by application of the law of the sea. The human rights of those who want to pass and perform the passage - in our case political rights such as the freedom of assembly - are in question.

\footnotetext{
${ }^{76}$ Libya notified the designation of its SAR region to the International Maritime Organization (IMO), first in July 2017, in a statement that was subsequently withdrawn, and then again in December 2017. The IMO confirmed the declaration of the Libyan SAR region in June 2018, see InTERnAtIonal MARITIME ORGANiZATION, https://gisis.imo.org/Public/COMSAR/ NationalAuthority.aspx; SEARCH AND RESCUE CONTACTS, https://sarcontacts.info/srrs/ly_srr/.

${ }^{77}$ See Death by Resuce, supra note 5; Blaming the Rescuers, supra note 5; Mare Clausum, supra note 5; Push-Back of the Nivin, supra note 5.

${ }^{78}$ Mann, supra note 2. Cf. Adel-Naim Reyhani, Absolute Rightlessness Sur Place through Excessive Externalisation-The Case of Libya, SSRN (2019), https://papers.ssrn.com/sol3/papers.cfm?abstract_id=3375300; Reyhani, supra note 18.

${ }^{79}$ Death By Rescue, supra note 5.

${ }^{80}$ See generally Annick Pijnenburg \& Conny Rijken, Playing Cat and Mouse: How Europe Evades Responsibility for its Role in Human Rights Abuses against Migrants and Refugees, in Mobile Africa: Human Trafficking and the Digital Divide (Mirjam Van Reisen et al. eds., 2019).

${ }^{81}$ UNCLOS, supra note 19, at art. 301.

${ }^{82}$ See Reyhani, supra note 78; Montevideo Convention on the Rights and Duties of States art. 1, Dec. 26, 1933, 165 L.N.T.S. 19, 49 Stat. 3097.

${ }^{83}$ For a useful discussion of the matter, see generally Dapo Akande, Recognition of Libyan National Transitional Council as Government of Libya, EJIL: TALK! (July 23, 2011), https://www.ejiltalk.org/recognition-of-libyan-national-transitionalcouncil-as-government-of-libya/.

${ }^{84} \mathrm{UNCLOS}$, supra note 19 , at arts. 2, 17.
} 
In short, the law of the sea provides a generally auspicious context for private volunteer rescue operations. In the way it reshuffles jurisdictional assumptions that seem firmer when one considers only territorial borders, it creates opportunities for transnational solidarity, and for the performance of rescue. Principles like the duty of rescue and the freedom of navigation construct this maritime environment. Yet these do not always suffice to establish accountability towards migrants at sea.

A possible illustration is that, perhaps tragically, the law does not currently provide the legal infrastructure for transportation initiatives aiming to ferry migrants - that would reduce drownings to zero-across the Mediterranean. The Malta-based Migrant Offshore Aid Station (MOAS) has thus had to constantly shake off the accusation of being a "ferry for migrants." ${ }^{25}$ Such initiatives risk clashing head-first into criminal law provisions against smuggling, ${ }^{86}$ and the idea that international law grants states the authority to enforce their borders.

\section{International Criminal Law}

Recently, lawyers have attempted to enforce the human rights of drowning migrants through an appeal to international criminal law, specifically the International Criminal Court (ICC). Described in these attempts are policies of detention, deportation, and torture-all framed as widespread or systematic attacks against a civilian population, and hence as crimes against humanity. ${ }^{87}$ Can international criminal law help establish accountability towards migrants in the Mediterranean maritime legal black hole ${ }^{88}$ If there is an accountability gap towards migrants crossing the Mediterranean, is international criminal law positioned to fill it?

For international criminal law to apply, an international crime needs to first be identified. Yet just like in the context of the right to life, most of the relevant cases may be about failing to rescue migrants when rescue was possible, but not squarely required: Not by positive duties stemming from the right to life, not by refugee law, and not by the law of the sea. These are cases where migrants have drowned beyond state jurisdiction; cases where the tragedy is one concerning a shortcoming of international law when a transit state collapses, not its lack of application. ${ }^{89}$ This presents an impasse for at least part of the international legal arguments marshalled in favor of migrants.

One international criminal law complaint illustrates the difficulty. In June 2019, lawyers Omer Shatz and Juan Branco submitted a communication to the ICC prosecutor, alleging that the European policy in the central Mediterranean during 2014-2019 amounts to multiple crimes against humanity. ${ }^{90}$ The submission argues for the investigation of European actors for crimes against humanity, including: murder (Article 7 1. a. of the Rome Statute); enslavement (Article 7 1. c.); rape (Article 7 1. g.); deportation (Article 7 1.d.); unlawful imprisonment

\footnotetext{
${ }^{85}$ See, e.g., The Success of the Migrant Offshore Aid Station (MOAS), Human Rights at SEA, (Dec. 10, 2014), https://www. humanrightsatsea.org/2014/12/10/the-success-of-the-migrant-offshore-aid-station-moas/.

${ }^{86} \mathrm{Cf}$. Protocol Against the Smuggling of Migrants by Land, Sea and Air, Supplementing the United Nations Convention Against Transnational Organized Crime, arts. 61(c), 62(b), Dec. 11, 2000, 2241 U.N.T.S. 507.

${ }^{87} \mathrm{See}$ Ioannis Kalpouzos' contribution to this Special Issue, International Criminal Law and the Violence against Migrants, in this issue. See also Kalpouzos \& Mann, supra note 15; Mann, Moreno-Lax \& Shatz, supra note 15.

${ }^{88}$ Note that I'm not interested, at this point, to find out whether international criminal law can be helpful as a matter of fact. I'm content to simply concede that international criminal law institutions may not be functioning properly, and therefore that the matter of fact answer is a resounding no. What I'm interested in is, rather, whether international criminal law can contribute, analytically, to establishing accountability on behalf of the migrants drowning at sea. That is, my focus is on whether international criminal law could establish such accountability if it worked "properly": according to its mandate when applied unbiasedly, according to rule of law standards, and with the necessary resources.

${ }^{89}$ See Itamar Mann, Killing by Omission, EJIL: TALK! (Apr. 20, 2016), https://www.ejiltalk.org/killing-by-omission/.

${ }^{90}$ Omer Shatz \& Juan Branco, Communication to the Office of the Prosecutor of the International Criminal Court, Pursuant to Article 15 of the Rome Statute (2014-2019), ACADEMIA (2019), https://www.academia.edu/39389018/EU_Migraiton_ Policies_in_the_Mediterranean_and_Libya_2014-2019_.
} 
(Article 7 1. e.); torture (Article 7 1. f.); persecution (Article 7 1. h); and other inhumane acts (Article 7 1.k). Regarding some of the allegations, European agents are accused as principal perpetrations. In others they are accused as a matter of secondary liability.

Some aspects of the communication are solid. It integrates a variety of sources to paint a grim picture of European authorities turning a blind eye to migrant deaths by drowning, and sometimes utilizing them for "deterrence" purposes. Further, it legally analyzes the enormous funding and support European actors have knowingly granted to abusive facilities in Libya. Particularly powerful are those claims concerning aiding and abetting Libyan forces in clear violations of international criminal law. If the ICC prosecutor were to act in an unbiased way, it would indeed be time to investigate European agents for crimes against humanity against migrants in Libya.

And yet, one specific argument raises analytic difficulties closely tied with the question of de jure rightlessness. This is the argument directed at drownings at sea-the argument that seeks to close the legal black hole at the center of the Mediterranean. It is framed as an argument on the international crime against humanity of murder, namely, that "European Union officials and their agents knowingly caused the death of members of a civilian population, within the meaning of article 7(1)(a) of the Rome Statute." 91 The authors argue that by omitting to fulfill their duties under (1) the right to life, (2) refugee law, and (3) the law of the sea, European agents have "caused" the deaths of thousands of migrants.

The actus reus component is purportedly fulfilled by an omission, not an action. Even if unusual, such a construction is possible under international criminal law, where the crime is an omission of pre-existing duty. To make this argument, the communication refers back to the language of the Rome Statue, which requires that elements of the crime include that "the perpetrator killed, or caused the death of, one or more persons." ${ }^{92}$ They therefore argue that a relation of causation between an underlying omission and the death at sea meets the requirements of the treaty. And they indeed provide authority for the statement that an omission is considered as an action, when a pre-existing duty to act had been breached. ${ }^{93}$ As indicated, the duties the authors cite are under the three bodies of law already discussed above. In the authors' words: "EU agents caused the death of thousands by (1) failing to fulfill (2) a duty to act, i.e. the duty to render assistance to civilians in life-risking situation under European Union and Member States' effective control." 94

Nevertheless, this assertion relies on an artificially broad construction of the underlying positive duties under each of the three bodies of law described above, not more than wishful thinking. It is not supported by the lex lata, and it is in tension with the basic structure of each of these bodies of law, as they are informed by the limitations of jurisdiction. Considering the right to life, the complaint simply assumes that the central Mediterranean area is under the jurisdiction of European states. There could be an argument that parts of the Mediterranean high seas are entirely under its de-facto control. ${ }^{95}$ But such an argument goes well beyond accepted notions of jurisdiction and can by no means simply be assumed. The same goes for refugee law. For better or worse, a state's obligations under refugee law are triggered only once an individual is under its jurisdiction.

As for the law of the sea, European actors' duty to render assistance is also artificially expanded, seemingly to cover the entire Mediterranean like a blanket. The idea is that during Mare Nostrum,

\footnotetext{
${ }^{91} I d$. at 134 .

${ }^{92} \mathrm{Id}$. at 134 .

${ }^{93}$ See id. at 133-35. They refer, for example, to Prosecutor v. Lubanga-Dyilo, Case No. ICC-01/04-01/06, Decision on the Confirmation of Charges, para. 352 (Jan. 29, 2007), https://www.icc-cpi.int/CourtRecords/CR2007_02360.PDF; Prosecutor v. Galic, Case No. IT-98-29-A, Judgement, paras. 149, 175 (Nov. 30 2006), https://www.icty.org/x/cases/galic/acjug/en/galacjud061130.pdf; Prosecutor v. Rutaganira, Case No. ICTR-95-1C-T, Judgement and Sentence, para. 79 (Mar. 14, 2005), https://unictr.irmct.org/sites/unictr.org/files/case-documents/ictr-95-1c/trial-judgements/en/050314.pdf.

${ }^{94}$ Shatz \& Branco, supra note 90, at para. 576.

${ }^{95}$ Shatz \& Branco, supra note 90.
} 
Italy has shown that it can rescue persons in the entire maritime area. And because it can, so goes the logic, the EU must. Once it was clear that lives were saved, a positive obligation emerged to continue Mare Nostrum - or another similar operation with a rescue mandate. ${ }^{96}$ But the duty to render assistance at sea doesn't go that far. The communication employs this duty, for the purpose of international criminal law, as the anchor for demonstrating that the omission amounted to a culpable act; when a preexisting duty is not acted upon, in turn causing deaths, the omission can furnish an actus reus requirement. That could be a tremendously valuable point, but only following a case-by-case analysis, which would isolate instances in which the duty indeed obtained. In their argument that once Mare Nostrum began there was a duty to continue with a similar operation, the communication conflates a "privilege" with a duty. ${ }^{97}$

The theory relying on widespread or systematic killing by omission of duties as a crime against humanity may sometimes be applicable. By introducing its outlines, the communication offers an important contribution. Yet it is limited to far fewer cases than the staggering number of deaths at sea since 2014. By reason of its legal structure, international criminal law cannot be relied upon to secure the rights of migrants who died by drowning, by coupling them with prosecutorial duties. For the fourth time, the maritime legal black hole remains.

\section{Rescuer Rights}

\section{The Right to Manifest Solidarity at Sea}

"It is not only migrants, however, who are being expelled from the sea," write Heller and Pezzani. ${ }^{98}$ Human rights law does, of course, provide rights to those seeking to render assistance, independently of the rights of those they seek to rescue. When they come closer to migrants in risk of dying, these actors also become subject to the maritime law duty to render assistance to vessels in distress. Part of the problem today is that often they cannot even approach the relevant maritime vicinities. Which rights should we be talking about as relevant to the mission of performing rescue?

One place to start is the freedom of conscience, enshrined in the relevant international human rights treaties, as well as in the constitutional law of European states. ${ }^{99}$ What is it that those who rescue migrants at sea are expressing, if not their conscience? The relevant provisions do not protect only beliefs, but also their manifestations. ${ }^{100}$ While conscience is surely at issue, conscience is not a form of action. We are not seeking protection to manifest our belief that migrants should be rescued at sea. We are seeking protection for the choice activists have made to physically go out to the Mediterranean Sea and rescue them.

More to the point is the freedom of expression. The text of both the European regional conventions focuses on the right to express one's views and receive information. ${ }^{101}$ The views expressed may differ for different activists. Some may cast these in humanitarian terms, seeing themselves as expanding the mission historically articulated by the founders of the Red Cross. ${ }^{102}$ On the other side of the spectrum, some may be there to express views about the nature

\footnotetext{
${ }^{96}$ Shatz \& Branco, supra note 90 , at paras. $622-24$.

${ }^{97}$ Hohfeld, supra note 3.

${ }^{98}$ Heller \& Pezzani, supra note 14 , at 647.

${ }^{99}$ International Covenant on Civil and Political Rights art. 18, Mar. 23, 1976, 999 U.N.T.S. 171; The European Convention on Human Rights (ECHR), art. 9, Nov. 4, 1950, E.T.S. 5; Charter of Fundamental Rights of the European Union (CFREU), art. 10, Dec. 18, 2000, 364 O.J. 01.

${ }^{100}$ See, e.g., European Court of Human Rights, Guideline on Article 9 of the European Convention on Human Rights, at 11 (2019), https://www.echr.coe.int/Documents/Guide_Art_9_ENG.pdf.

${ }^{101} I d$.

${ }^{102}$ Such is a rather grim view, as it seemingly accepts that the Mediterranean has become a battlefield and does not seek to terminate the need for such rescue missions.
} 
of a multicultural society, a European debt to postcolonial peoples, or global inequality. ${ }^{103}$ What is nevertheless important is that any such mission carries with it a message. The aspect of receiving information is squarely pertinent, because a major part of restricting rescue activities is about states seeking to avoid being seen. It is precisely for this reason that Proactiva Open Arms, for example, has made the conscious choice to prioritize room for independent journalists on its rescue ships. ${ }^{104}$ As Giorgia Linardi, spokesperson for Sea Watch, has explained: "We are civil society at sea. But now we are not at sea because it is no longer allowed for civil society to know what is happening at sea."105

Moreover, freedom of expression is not only about expressing views or receiving information, but also about the freedom to take to the streets and protest. Freedom of expression is important not only for protecting one's own narrow interests, but also for views that are directed at the prevention of harm or even atrocity towards others. Finally, freedom of expression scholars have given us the analytic framework to understand the "chilling effect" that we have seen in Mediterranean rescue operations. ${ }^{106}$ This dynamic also highlights the importance of a freedom of expression framing for the problems of migrant rightlessness.

Ultimately, however, perhaps the most important anchor for a right to perform rescue is the right to freedom of assembly and association. ${ }^{107}$ The very title of this right is crucial. What does it mean, in this context, to talk about the freedom of assembly? ${ }^{108}$ As Judith Butler has noted following the Occupy Wall Street movement of 2011, the very fact of people gathering "says" something without always relying on speech. ${ }^{109}$ The word "assembly" invokes the assemblage of people convening together against the seascape backdrop, a political-humanitarian performative act. ${ }^{110}$ Rescue operations are ultimately not only about saving lives, but also about associating with others. Thus, it is not only the freedom of assembly, but also the freedom of association.

This reasoning follows the ECtHR's judgment in Women on Waves v. Portugal. ${ }^{111}$ In that case, the court found that Women on Waves's protest activity against abortion restrictions in Portugal's territorial waters was protected by Articles 10 and 11 of the European Convention on Human Rights (freedom of expression and freedom of association, respectively). In light of this interpretation, it also found that Women on Waves entered Portuguese territorial waters in an instance of "innocent passage."112

Rescue activities beyond European jurisdiction do not always occur in territorial waters. When they don't, they enjoy a more auspicious maritime legal environment. The freedom of navigation is on their side. When they do enter territorial waters, human rights inform the interpretation of the Law of the Sea and should similarly frame their movement as "innocent passage" - as the

\footnotetext{
${ }^{103}$ See generally Nina Violetta \& Maurice Steirl, Amplifying Migrant Voices and Struggles as a Radical Practice, 118 S. ATL. Q. 661 (2019); Tendayi Achiume, Migration as Decolonization, 71 STAN. L. Rev. 1509 (2019).

${ }^{104}$ Conversation during meeting with Proactiva Open Arms communications director Laura Lanuza, Badalona, Spain (Nov. $5,2019)$.

${ }^{105}$ Sea-Watch, Diskussion im Bundestag - Diskussion mit Karl Kopp, Giorgia Linardi und Violeta Morena-Lax [Discussion in the Bundestag - Discussion with Karl Kopp, Giorgia Linardi and Violeta Morena-Lax], YouTube (Oct. 14, 2018), https://www. youtube.com/watch?v=U2b3O_Cbngc. The discussion panel "Zukunft der zivilen Seenotrettung" ["The Future of Civil Sea Rescue"] was convened by Die Linke on September 13, 2018.

${ }^{106}$ See, e.g., Frederick Schauer, Fear, Risk, and the First Amendment: Unravelling the "Chilling Effect", 685 B.U. L. REV. 58 (1978).

${ }^{107}$ International Covenant on Civil and Political Rights (ICCPR) art. 19, Dec. 16, 1966, G.A. Res. 2200A (XXI); ECHR, supra note 99, at art. 11; CFREU, supra note 99, at art. 12.

${ }^{108} \mathrm{Cf}$. Michael Hardt \& Antonio Negri, Assembly (2017).

${ }^{109}$ Judith Butler, Notes Toward a Performative Theory of Assembly (2015).

${ }^{110}$ Note that Schlag's call to go back to Hohfeld, which I have referred to above, also makes a tacit reference to speech-act theory, which is part of the philosophical background for Butler's theory of performance. Schlag, supra note 21; J.L. AUsTiN, How to Do Things with Words (2011).

${ }^{111}$ Women on Waves v. Portugal, App No. 31276/05 (Mar. 2, 2009), http://hudoc.echr.coe.int/eng?i=001-61572.

${ }^{112} I d$. at para. 16 .
} 
ECtHR decided in Women on Waves. ${ }^{113}$ Finally, the nature of the activity as one of rescue may also militate toward a broad protection of activists' rights. Because migrants at sea risk death, activists' rights to assembly in their area are rendered weightier - especially when states refuse to save lives or employ drowning as "deterrence." The rights of activists, at least inasmuch as they are nationals of the states that seek to prevent their activity_-but that have human rights obligations to respect it - do not present a problem of jurisdiction. In this regard, legal obligations towards activists, even when they act extraterritorially, are structured differently from those towards migrants. The state has duties to respect and to protect its citizens' freedom of expression whether they act territorially or extraterritorially; it cannot argue that extraterritorial interference with their political rights is beyond its human rights jurisdiction. Thus, the rights of rescue activists and drowning migrants are somehow mutually constitutive, when they come to encounter each other at sea. ${ }^{114}$

What are the stakes in talking about rescue operations at sea in terms of the human rights of rescuers? First, one may object on a moral level: The widespread migrant drownings we have seen for so many years are surely not primarily about rescuers' civil and political rights. Whether the latter are German volunteers or Italian fishermen, they belong to a relatively secure and privileged party. We should therefore insist on legal vocabularies that center upon the rights of migrants, and on the dire consequences that "Fortress Europe" has had for them. Or, in other words: Massive drowning is much graver a loss than any breach of political rights that rescuers may suffer. Focusing on the latter is at best missing the point, and at worse a cynical exercise in solipsism.

This may sound true. But the legal strategy one employs must not be such a zero-sum game. One can talk both about the rights of migrants and about the rights of rescuers, without one overshadowing the other. One can acknowledge the limits of jurisdiction currently resting upon the right to life, while seeking to expand them. And one can still admit that the law grants no air-tight protections for migrants at sea, that it has been a source of peril for them as often as it has been a source of remedy. ${ }^{115}$ Furthermore, involving oneself in a project of rescue that is now being aggressively criminalized, and then saying "it is not about me" may also be a form of self-aggrandizement. It reflects the fantasy that a rescuer should never have to fight for what they believe in; the message they deliver is ostensibly above any such struggle.

Second, speaking of rescue operations in terms of human rights does not grant absolute protections for everyone who assists individuals in entering Europe. It may indeed invite further state curtailments on solidarity in the Mediterranean: After all, civil and political rights are always subject to proportional limitations. ${ }^{116}$ In the same vein, the duty to rescue and to deliver rescuees to a place of safety cannot result in a violation of the prohibition of human smuggling. A duty carries more weight than a right, which could be limited by immigration law concerns. But this too is not a weighty objection. Once we see manifestations of solidarity at sea as what they are, namely the exercise of a right, we come to realize: Anti-trafficking and anti-smuggling laws cannot be misused to apply to those who save lives at sea, even if their action leads to disembarkations on European shores. They, too, must be limited in scope, to encroach upon migrants' right to life as little as possible - when jurisdiction is established-as well as upon the civil and political rights of European rescue volunteers - when the migrants are beyond European jurisdiction and therefore their right to life grants them no real protections. Perhaps more importantly, as the next part of this Article emphasizes, any encroachment upon civil and political rights is subject to renegotiation and pressure when the right is exercised. Rather than having pre-determined contours, the

\footnotetext{
${ }^{113} I d$. at paras. 29-31. See also UNCLOS, supra note 19, at arts. 17-19. In particular, Article 19(1) provides that "[p]assage is innocent so long as it is not prejudicial to the peace, good order or security of the coastal State."

${ }^{114}$ This mutual constitution is what I have called "the human rights encounter." See MANN, supra note 17, at ch. 1.

${ }^{115}$ See Wilde, supra note 39.

${ }^{116} \mathrm{ICCPR}$, supra note 107 , at arts. 4-5.
} 
right to assembly is the result of what those who seek assembly make of it. ${ }^{117}$ To paraphrase Marie-Bénédicte Dembour's felicitous terminology, this right is a "protest right," in the sense of always being born out of someone's fight for it. ${ }^{118}$

Third, one might raise a concern we have all grown ever more familiar with. Casting political action in terms of its legal protections, and expecting judges to enforce rights absent popular support, may lead to yet more backlash against the courts. While this concern is valid, and expansive interventions by courts may have adverse consequences, it is not unique to the present context. It is common to any attempt to protect the rights of non-members of the polity. Any litigation enforcing this right must be strategic and go hand in glove with broader political mobilization. Perhaps most importantly, the right discussed here does not start from an appeal to courts. It starts from the direct action of solidarity activists. Litigation efforts will be protected by continued action at sea, just as much as litigation can potentially enforce the right to such action.

A fourth objection to the above argument is that it construes solidarity towards asylum seekers too narrowly. Why limit solidarity to cases of rescue, or even showcase the latter as its paradigmatic examples? More far-reaching action, for example, may include ferrying those in need of protection from the Southern to the Northern coast of the Mediterranean. This kind of direct action would realize the latter's right to leave a country, protected both by the Universal Declaration of Human Rights, and by the European Convention on Human Rights. And it would also lean on the basic civil and political rights of those who initiate such activity, including their freedoms of expression and association. While a legal argument defending such an ambitious action requires full consideration elsewhere, it lacks a component that will ultimately be central to my argument here: At no point in time does this form of solidarity become a duty of the rescuers, as it is at sea under Article 98 UNCLOS. This moment of transformation of the right to manifest solidarity into a duty to render assistance is what I have referred to above as the closing of a circle.

Stressing the extraordinary encroachment that the criminalization of rescue activities places upon the civil and political rights of rescuers may have the practical result of casting some of the relevant criminal provisions as illegal. The relevant fora for such a discussion are not limited to international law. European democracies protect the relevant civil and political rights under their domestic law as well. As already mentioned above, an added benefit of such a framing is that the jurisdictional problems that consistently cropped up in other contexts are solved. When a European government limits the rights of its own citizens, both constitutional courts and the European Court of Human Rights can exercise judicial review. Jurisdiction is established over members of the polity, whether they are in the relevant state territory or not. ${ }^{119}$ This probably remains true when we are talking about common membership in the EU supranational polity, such as the case when Italy criminalizes the activity of German activists.

\section{Maritime Civil Disobedience}

When we argue the illegality of criminalization measures against political activity, we may need to persist with the underlying activity for the argument to be heard. In other words, the criminalized political activity must continue even while a relevant government frames it as illegal. Such activity is a kind of civil disobedience. While exercising it, activists present a challenge. They claim that

\footnotetext{
${ }^{117}$ See ARENDT, supra note 22.

${ }^{118}$ Dembour suggests "that there are four main concepts of human rights which are in competition with each other. To present them in the briefest manner, those I call 'natural scholars' conceive of human rights as given; 'deliberative scholars' as agreed; 'protest scholars' as fought for; and 'discourse scholars' as talked about.” MARIE-BÉnéDiCTE DembOUR, Who BeliEves in Human Rights? Reflections on the European Convention 232 (2010).

${ }^{119}$ Indeed, the rights of Libyan human rights activists or Tunisian fishermen to perform their own rescue activities requires a different analysis. It does not trigger the jurisdiction of human rights institutions in the same way.
} 
their interpretation of the relevant law is more accurate than the government's, ${ }^{120}$ and that therefore, they are better placed to uphold the law. Thus, for example, when the Sea Watch 3 was released from a five-month detainment in a Sicilian port, Sea-Watch Chairman Johannes Bayer exclaimed: "Sea-Watch and other civil rescuers are the only ones upholding the law, which was proven again today." ${ }^{21}$ To succeed, this strategy must aim to be convincing for a larger transnational audience, which may help in shaming the government that criminalized said activity. Rescue at sea is an important example of contemporary civil disobedience, sharing certain aspects with earlier historical precedents. ${ }^{122}$ A brief foray into a political theory buttressing earlier precedents may illuminate the current moment.

In her essay Civil Disobedience, Hannah Arendt argued that the protection of non-violent, politically motivated "crime" was a missing part of the American constitution. ${ }^{123}$ The essay was first published in 1970, and Arendt wrote against the backdrop of a newfound discourse of "law and order" - a conservative response to the civil rights movements of her time. While civil disobedience is not explicitly protected by the American constitution, Arendt claimed that its underlying assumptions were a distinct part of the American social contract. She traced its roots back to the founding fathers of the United States, and she argued for its constitutional recognition, in a doctrine that would ostensibly be a part of the First Amendment-which protects the freedom of conscience, the freedom of speech, and the freedom of assembly and association.

One of her important distinctions in the essay is between civil disobedience and conscientious objection. On the one hand, unlike civil disobedience, conscientious objection does not seek a change in the world. It is, rather, aimed to protect the objector from the possibility of participating in an act they find fundamentally immoral. Arendt's quintessential examples of conscientious objection are the choices of Socrates and Henry David Thoreau. These figures embody a refusal to obey law that is in violation of their fundamental moral convictions. They insist on the cleanliness of their own hands. ${ }^{124}$

Civil disobedience, on the other hand, is not about personal conscience, but about publicly held opinion. It gains its strength and validity from the fact that many people practice it, expressing the same basic ideas and interests, and demanding their recognition as rights. This allows a measure of objectivity that conscientious objection can never have on its own accord. Civil disobedience is a mechanism for taking a stance and increasing its visibility in the public sphere. It aimed to legalize refusal of combat duty during the possibly illegal war in Vietnam. And Arendt compares it to strikes and collective bargaining rights in labor law. All of these can empower relatively disempowered groups and increase their negotiating power-sometimes in dramatically significant ways:

The Constitution itself offer a quasi-legal way to challenge the law by breaking it ... Is it not obvious that this legal action - very significant indeed - was the result of civil disobedience of draft resisters, and that its aim was to legalize servicemen's refusal to combat duty? The whole body of labor legislation - the right to collective bargaining, the right to organize and to strike - was preceded by decades of frequently violent disobedience of what ultimately proved to be obsolete laws. ${ }^{125}$

\footnotetext{
${ }^{120} \mathrm{Cf}$. Thomas Gammeltoft-Hansen \& Tanja Aalberts, Sovereignty at Sea: The Law and Politics of Saving Lives in the Mare Liberum (DIIS, Working Paper 2010:18), https://pure.diis.dk/ws/files/43394/WP201018_sovereingty_at_sea_mare_liberum_ web.pdf (discussing interpretation in this context).

${ }^{121}$ See Germany's Sea Watch, supra note 9.

${ }^{122} \mathrm{Cf}$. an extremely illuminating draft paper by Frédéric Mégret, Activists on the High Sea: Reinventing International Law from the Mare Liberum? (2020) (working paper) (on file with author).

${ }^{123}$ ARENDT, supra note 22.

${ }^{124}$ ARENDT, supra note 22, at 60.

${ }^{125}$ ARENDT, supra note 22 , at 80.
} 
Rather than allowing the right-bearer to exit the consequentialism of political calculation, as does conscientious objection, civil disobedience is exercised precisely in order to bring about particular consequences. Arendt's paramount example of the success of civil disobedience is the way it influenced the decisions of the United States Supreme Court in the abolition of slavery. ${ }^{126}$ But she also grants that the distinction between conscientious objection and civil disobedience isn't airtight, and in some circumstances, it seems to collapse. "No doubt even ... conscientious objection can become politically significant when a number of consciences happen to coincide, and the conscientious objectors decide to enter the market place and make their voices heard in public." 127

Today, private rescue operations in the Mediterranean are a form of transnational maritime civil disobedience. ${ }^{128}$ Just like Arendt argued that civil disobedience should be recognized as part and parcel of the American constitution, rescue activities are a form of transnational civil disobedience that should be recognized as part and parcel of international law. It is implicit in a system that otherwise creates gaps where governmental power can go unchecked. And it is the only mechanism that can truly seek to eliminate the spaces of de jure rightlessness that have appeared as maritime legal black holes. It is thus not human rights tribunals or committees - or the international criminal court - that has the primary responsibility to provide accountability where no other accountability exists. It is the responsibility of rights-bearing subjects of the law. True, the presence of individual witnesses may later be decisive for other forms of rights-enforcement. For example, it may be decisive in preparing a robust claim before a domestic court, an application to the ECtHR, or an international criminal complaint. But the basis for closing such black holes is always first and foremost direct action, when backed by collective will and organized accordingly. If I may use such terms, by placing themselves in the proximity of those among us who have been rendered rightless, solidarity activists generate a kind of legal energy field. Their presence transforms their own rights into duties (of rescue); but it also projects much further and influences accountability that advocates may seek to establish under a host of other transnational legal regimes.

As I introduce this final argument, you may find yourself slightly disappointed. I have discarded overly-expansive readings of the right to life, refugee law, the law of the sea, and international criminal law. How can I afford to advance what seems to be a "wishful" reading of political rights such as the right of assembly? The right to exercise maritime civil disobedience, you may say, is no more protected under the lex lata, than the duty to protect the right to life in spaces of debatable jurisdiction.

There is something to this objection. Ultimately, there may be more space for re-interpretation of each of the bodies of law described above than I have seemed to allow. ${ }^{129}$ But if that is the case, such reinterpretations rely on the pre-condition of exercising the right to manifest solidarity at sea. The latter is more foundational to the enforcement of universal human rights protections, because its binding nature begins from popular direct action, not from appeals to authority-judicial or other. It is unreasonable to expect that governments will simply apply humanitarian interpretations of the law in order to preserve "the integrity of international law" if not actively pressured to do so. ${ }^{130}$ The preconditions in which such a duty arises need first to be contested. Even if the law of the sea requires that we perform rescue, the obligation does not always exist: Someone who wants to carry out the duty must go and voluntarily place themselves in a position in which they will be

\footnotetext{
${ }^{126}$ ARENDT, supra note 22 , at 81 .

${ }^{127}$ ARENDT, supra note 22 , at $67-68$.

${ }^{128}$ At least when confronted with claims concerning violations of law-for example, anti-smuggling laws. This has usually been tied to issues concerning disembarkation, as discussed below.

${ }^{129}$ See, e.g., Violeta Moreno-Lax, Daniel Ghezelbash \& Natalie Klein, Between Life, Security and Rights: Framing the Interdiction of 'Boat Migrants' in the Central Mediterranean and Australia, 32 LEIDEN J. INT'L L. 715 (2019).

${ }^{130} I d$. at 3 .
} 
obliged to do so. ${ }^{131}$ While the scope of governmental duty to protect the freedom of expression or the freedom of assembly is not determinable a priori, it is unquestionable that such a duty exists.

The simple diagram below illustrates a condition of de-jure rightlessness for person $a$ transforms into a condition of having a right, thanks to the exercise of political rights by person $b$ :

- Person $b$ is a citizen of state $x$. She therefore has a right to exercise civil and political rights, encompassing her freedom of expression and right to assembly and association. State $x$ has a duty to protect the civil and political rights of person $b$, which includes movement for solidarity activities upon maritime spaces.

- Conversely, person $a$ is in distress at sea, beyond state $x$ 's jurisdiction (or beyond its SAR zone). She wants to live but does not strictly speaking have a right to life, in the sense that neither state $x$, nor any other state, has a duty to rescue her. Of course, state $x$ has a privilege to rescue person $a$, which means that the state can do so if it decides to-see discussion above of Mare Nostrum. ${ }^{132}$

- Although, when person $b$ is close enough, receives person $a$ 's distress signal, and is able to do so, person $b$ has the duty to rescue person $a$. Person $a$ is thus included within the scope of law's protection.

- The same remains true if person $b$ exercises her right while state $x$ does not respect it, for example, by way of civil disobedience. Person $b$ would then have to continue to carry out direct bottom-up pressure until her right is recognized, by implication extending rights protections to person $a$.

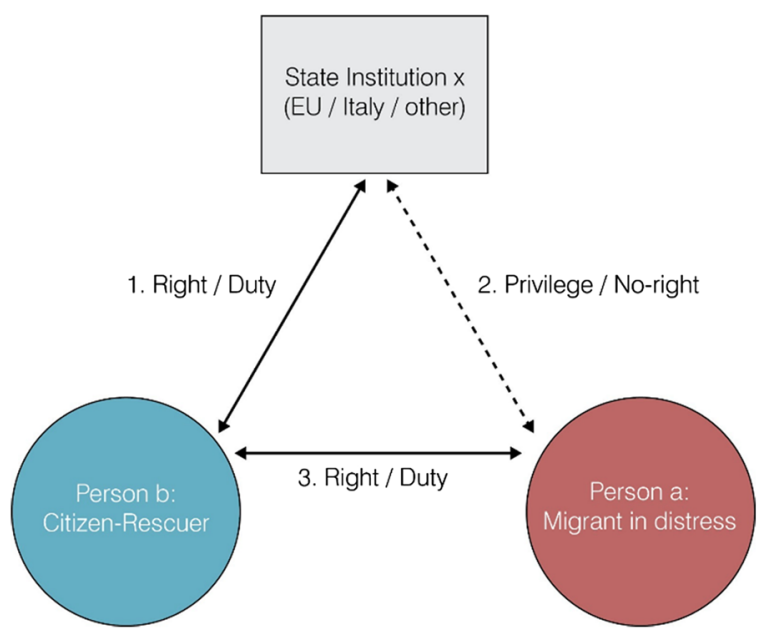

Once activists are located in a shared space of assembly with migrants and asylum seekers, they participate in reshaping the conditions for other sources of law to apply. At this point, the most crucial questions become those of the right to life, refugee law, and the law of the sea-as well as ultimately all the human rights that migrant may enjoy, like any other person. In getting there, the

\footnotetext{
${ }^{131}$ Such encounters, I dare say, are somehow foundational to international law.

${ }^{132}$ If the state exercises its SAR authority over the rescuers, ordering them to rescue, their action is arguably attributable to the SAR state - and to their flag state ordering them to follow the RCC's instructions — creating another possible rights link.
} 
first question after rescue is: Where will the rescued migrants be disembarked, and what rights will they secure once on land?

Since the summer of 2019, the main arena for maritime civil disobedience arguably occurred after-rather than before - the initiation of rescue operations. As Italy declared that it has decided to close its ports and bar the disembarkation of migrants, the rescue vessels of organizations such as Sea Watch and Proactiva Open Arms faced them off. In apposite example, the Sea Watch 3 vessel entered Italy's territorial waters, and then the port of Lampedusa, as place of refuge, citing an emergency on board. These operations clearly placed the ship, and its passengers, in the territorial jurisdiction of Italy. In the territorial zone, the migrants can already rely on the Asylum Procedure Directive, which confers a number of procedural rights that go beyond human rights. ${ }^{133}$ This strategy of civil disobedience is necessary for establishing accountability at sea. Without it, migrants may be disembarked in Libya, where they suffer gross human rights abuses and sometimes death.

\section{E. Conclusion}

Because of jurisdictional rules, migrant rights may not be the sufficient basis for securing migrants' real-life protections. ${ }^{134}$ Rescuer rights may provide the necessary ground for joining migrants' claims with specific addressees, coupling their own rights to rescuers' duties. Governments have understood this, motivating them to try to drive activists away. Yet strategies aiming to deter rescue operations may implicate governments with both domestic and international illegality. Under international law, regional human rights law, and domestic constitutional systems, such deterrence and criminalization strategies may be deemed illegal. Any jurisdictional hurdles stemming from the creation of maritime legal black holes in the Mediterranean can be surmounted: There are no jurisdictional challenges in claiming the protection of citizens by their governments. Measures directed at European civil society activists can thus be struck down as disproportionately encroaching upon the right to manifest solidarity at sea.

Policies aimed to "deter" rescue activities do not only lead to the loss of lives at sea. They may also violate the civil and political rights of those who seek to perform acts of rescue. This has been true for volunteer groups like Sea Watch, SOS Mediteranea, Proactiva Open Arms, and Mare Liberum, as well as of individuals such as numerous Italian fishermen, who have over the years resisted the various kinds of border violence that EU Member States have employed. They have all exercised their freedoms of expression, association, and assembly in extending helping hands to migrants. By approaching migrants and providing them with company at sea, they have, voluntarily, turned themselves into the bearers of duties corresponding to migrant rights. The right to perform rescue is supported by extant law but can only be enforced from below-through action by activists, including by a form of civil disobedience.

European policies nearly shut down solidarity activities in the central Mediterranean during summer 2019. Fewer private rescue vessels than ever are currently patrolling the area, and the activities of Libyan authorities are becoming ever more entrenched. Without the presence of private rescue initiatives, the central Mediterranean has thus become, once again, an area of de-jure rightlessness. But the cat-and-mouse game of disobedience will continue around this lacuna. ${ }^{135}$ Activists will continue to assert the right to manifest solidarity at sea. The only

\footnotetext{
${ }^{133}$ See Matthew Holroyd, Why Did Sea-Watch 3 Decide to Enter Italian Territorial Waters?, Euronews (June 27, 2019), https://www.euronews.com/2019/06/26/why-did-sea-watch-3-decide-to-enter-italian-territorial-waters.

${ }^{134}$ For a helpful critical account of the role of international law in the protection of migrants, see Jaya Ramji-Nogales, Undocumented Migrants and the Failures of Universal Individualism, 47 VAN. J. TRANSNAT'L. L. 699 (2014).

${ }^{135}$ Thomas Gammeltoft-Hansen \& James C. Hathaway, Non-Refoulement in a World of Cooperative Deterrence, 53 COLUM. J. Transnat'L L. 235, 246 (2015); Pijneburg \& Rijken, supra note 80.
} 
way to extinguish it is systematic encroachment upon civil and political rights: A form of European authoritarianism.

De jure rightlessness is central to explaining the place of solidarity within the global legal environment. It is precisely because some people have no de jure rights, that a right like the freedom of assembly and association is so central to the current predicament. The freedom of assembly and association buttresses solidarity activists' decisions to put themselves in positions where they have, under the law of the sea, a duty to rescue migrants. With their right-bearing bodies, solidarity activists devise the fulcrum upon which migrant rights come to exist in the first place, in spaces from which they would otherwise be eliminated. By being there and invoking their own rights, they ensure that the migrants have rights. Although de-jure rightlessness is seldom acknowledged in international law, many migrants crossing the Mediterranean have fallen into this condition, absent the presence of solidarity activists. The latter, therefore, have such a foundational role. 